\author{
Renata Möhr Nemčić, Sandra Bradarić-Jončić \\ sandra.bradaric-joncic@erf.hr \\ Edukacijsko-rehabilitacijski fakultet Sveučilišta u Zagrebu \\ Hrvatska
}

\title{
Relacije kulturnog identiteta i samopoštovanja, zadovoljstva životom te psihičkog zdravlja gluhih i nagluhih osoba ${ }^{1}$
}

\begin{abstract}
Sažetak
Rezultati dosadašnjih malobrojnih istraživanja, iako u određenoj mjeri nekonzistentni, upućuju na povezanost kulturnog identiteta gluhih $\mathrm{i}$ nagluhih osoba $s$ njihovim samopoštovanjem i zadovoljstvom životom. Cilj ovog istraživanja bio je ispitati povezanost samopoštovanja, zadovoljstva životom i psihičkog zdravlja gluhih i nagluhih osoba sa sastavnicama kulturnog identiteta (kulturne identifikacije, kulturnih sklonosti, sudjelovanja u kulturi, samoprocjene kulturnih znanja i jezične kompetencije u znakovnom i hrvatskom jeziku) te vrstom kulturnog identiteta (čujući, marginalni, gluhi i dvokulturni). U istraživanju su sudjelovale 443 osobe oštećena sluha u dobi od 18 do 87 godina iz 17 hrvatskih gradova. Ispitivanje je provedeno primjenom Akulturacijske skale DAS (Maxwell-McCaw i Zea, 2011), Rosenbergove skale samopoštovanja (Rosenberg, 1965), Dienerove Skale zadovoljstva životom (Diener i sur., 1985) te četiri podskale upitnika o zdravlju SF-36 (Ware i Sherbourne, 1992), koje mjere opće psihičko zdravlje. U obradi podataka korišteni su regresijska analiza i KruskalWallisov test. Identifikacija sa zajednicom odnosno kulturom Gluhih pokazala se značajnim prediktorom samopoštovanja, zadovoljstva životom i psihičkog zdravlja gluhih i nagluhih osoba. Značajnim prediktorima samopoštovanja pokazale su se također varijable samoprocjene jezične kompetencije u znakovnom i govornom jeziku, varijable znanja o čujućoj kulturi i kulturi Gluhih (posljednja je negativno povezana sa samopoštovanjem) te sklonosti jednoj odnosno drugoj kulturi (obje negativno povezane sa samopoštovanjem). Značajnim
\end{abstract}

\footnotetext{
${ }^{1}$ Istraživanje je provedeno u okviru znanstvenog projekta "Dvojezična komunikacija gluhih i čujućih", poduprtog od strane MZOŠ RH.
} 
prediktorom zadovoljstva životom, uz identifikaciju s kulturom Gluhih, pokazala se i varijabla znanja o kulturi Gluhih. Sa psihičkim zdravljem, uz identifikaciju s kulturom Gluhih, povezanom se pokazala varijabla znanja o kulturi čujućih. Značajne razlike među gluhim i nagluhim osobama s različitim vrstama identiteta utvrđene su samo u odnosu na zadovoljstvo životom, pri čemu su najviše rezultate, kao i u prethodnim istraživanjima, postigle osobe $s$ dvokulturnim identitetom, a najniže osobe $s$ marginalnim identitetom. I na varijablama samopoštovanja i psihičkog zdravlja osobe s marginalnim identitetom postigle su najniže rezultate, ali ne značajno niže od preostalih skupina sudionika.

Ključne riječi: kulturni identitet, kultura Gluhih, znakovni jezik, samopoštovanje, zadovoljstvo životom 


\section{UVOD}

\subsection{Kulturni identitet i samopoštovanje}

Kulturni identitet pojedinčev je osjećaj pripadnosti određenoj kulturnoj zajednici. O zajednici gluhih govori se kao o kulturi Gluhih - kulturnoj manjini s vlastitim jezikom, običajima, vrijednostima, poviješću, stvaralaštvom, organizacijama (Lane i sur., 1996), a sve više i kulturno-specifičnim dvojezičnim pristupom u obrazovanju (Neil Mahshie, 1995; Teruggi, 2014; Marschark i sur., 2014).

Ovisno o razvojnim okolnostima, odnosno specifičnim demografskim varijablama vezanima uz slušni i obrazovni status (stupanj i vrijeme nastanka oštećenja sluha, slušni status roditelja i jezik kojim se komuniciralo u obitelji, vrsta škole koju su osobe pohađale i jezik kojim se u njima komuniciralo, posjećivanje kluba gluhih), gluhe i nagluhe osobe mogu formirati različit kulturni identitet. Neke će se identificirati s kulturom Gluhih i njezinim vrijednostima i običajima te formirati gluhi identitet, koji uključuje preferiranu upotrebu znakovnog jezika i preferirano sudjelovanje u životu zajednice gluhih. Neke će preferirano koristiti govorni jezik i sudjelovati u životu zajednice čujućih, identificirat će se s čujućom kulturom i formirati čujući identitet. Neke će se, pak, identificirati s objema kulturama, komforno se koristeći obama jezicima i aktivno sudjelujući u životima obiju kultura te formirati dvokulturni identitet, dok se neke neće identificirati niti s jednom od dviju kultura te ce tako formirati marginalni identitet (Glickman i Carey, 1993; Maxwell-McCaw, 2001; Leigh, 2009).

Prema akulturacijskom modelu kulturnog identiteta autorica Maxwell-McCaw i Zea (2011), kulturni identitet gluhih i nagluhih sačinjen je od pet sastavnica - faktora koji su ekstrahirani faktorskom analizom i na temelju njih konstruiran je mjerni instrument: DAS - Deaf Acculturation Scale (Maxwell-McCaw i Zea, 2011). Prema ovom modelu, sastavnice kulturnog identiteta su sljedeće: kulturna identifikacija ("Ugodno se osjećam u društvu gluhih."), sudjelovanje u kulturi ("Koliko uživate ići na kazališne predstave s gluhim glumicama i glumcima?"), kulturne sklonosti ("Više bih volio/voljela ići u školu za gluhe."), jezična kompetencija ("Koliko dobro koristite znakovni jezik?") te kulturno znanje ("Koliko dobro poznajete važne događaje u povijesti zajednice gluhih?"). Skala DAS, dakle, mjeri tih pet faktora u odnosu na identifikaciju sa svakom od dviju kultura te se kombinacijama rezultata na dvjema skalama utvrđuje vrsta identiteta (čujući, marginalni, gluhi, dvokulturni). 
Malobrojna dosadašnja istraživanja ukazuju na važnost izgrađenog kulturnog identiteta i njegovu povezanost sa samopoštovanjem i zadovoljstvom životom u gluhih i nagluhih osoba (Maxwell-McCaw, 2001; Hintermair, 2008).

Samopoštovanje je vrijednosna komponenta samopoimanja, odnosno subjektivni emocionalni doživljaj vlastite vrijednosti u pojedinca (Erol i Orth, 2011). Ono predstavlja relativno stabilnu osobinu, iako oscilira tijekom razvojnih stadija u životu pojedinca (Orth i Robins, 2014). U djetinjstvu je samopoštovanje relativno visoko, tijekom adolescencije opada, da bi nakon nje ponovo raslo i svoj vrhunac doseglo u dobi između 50 i 60 godina, nakon čega ponovo i ubrzano opada (Orth i Robins, 2014). Razvoj samopoštovanja tijekom djetinjstva i adolescencije ovisi o nizu intraindividualnih i socijalnih čimbenika, pri čemu su privrženost i prihvaćenost od strane važnih drugih osoba, naročito roditelja i vršnjaka, odnosno slika koju oni reflektiraju pojedincu, naročito u odnosu na njegovu kompetentnost, presudni (Mann i sur., 2004). Ono je jedna od najznačajnijih komponenata mentalnog zdravlja i zaštitni je faktor od negativnih utjecaja koji ga ugrožavaju; nestabilan pojam o sebi i nisko samopoštovanje mogu imati ključnu ulogu u razvoju poremećaja poput depresije, anoreksije, bulimije, anksioznosti, agresivnosti i zloporabe opojnih sredstava (Mann i sur., 2004). Samopoštovanje je povezano s uspješnim nošenjem sa stresnim situacijama, fizičkim zdravljem, postizanjem školskog i profesionalnog uspjeha te zadovoljstvom u partnerskim odnosima (Erol i Orth, 2011).

Teškoće komunikacije s okolinom, teškoće u razvoju privrženosti s drugima, neprihvaćenost od strane okoline i mogući osjećaji nekompetentnosti u usporedbi $s$ čujućim vršnjacima, mogu se negativno odraziti na samopoštovanje gluhe i nagluhe djece. Istraživanja samopoštovanja u gluhih i nagluhih osoba provedena su najčešće $s$ djecom i mladima, dok su istraživanja s odraslima rijetka. Ta istraživanja nisu dala jednoznačne rezultate: po nekima su gluhi i nagluhi sudionici postigli niže rezultate od čujućih (Capelli i sur., 1995; Van Gent i sur., 2012; Theunissen i sur., 2014), dok u drugima nisu utvrđene razlike (Cates, 1991; Percy-Smith i sur., 2008; Eriks-Brophy i sur., 2012). Također, po pitanju vrste škole koju su pohađali, rezultati nisu konzistentni. U nekima su više samopoštovanje iskazali sudionici iz redovnih škola (Leigh i sur., 2009; Mejstad i sur., 2009), u drugima oni iz posebnih škola (Obrzut i sur., 1999; Van Gurp, 2001; Theunissen i sur., 2014), dok treća nisu utvrdila povezanost (Bat-Chava, 1993; Kluwin i sur., 2002; Jambor i Elliot, 2005). Jedini rezultat koji je konzistentan jest povezanost slušnog statusa roditelja i načina komunikacije u obitelji. Višu razinu samopoštovanja postižu gluha djeca gluhih 
roditelja u odnosu na gluhu djecu čujućih roditelja (Bat-Chava, 1993) i općenito ona djeca i mladež koja u obitelji komuniciraju znakovnim jezikom (Leigh, 1999; Crowe, 2003; Hintermair, 2008) ili "totalnom komunikacijom" (simultanim korištenjem govornog i znakovnog jezika) (Desselle, 1994).

Rezultati istraživanja povezanosti kulturnog identiteta i samopoštovanja gluhih i nagluhih osoba također nisu jednoznačni. Bat-Chava je (1994) utvrdila višu razinu samopoštovanja kod gluhih osoba koje su u većoj mjeri orijentirane prema zajednici gluhih, u odnosu na one koje su se identificirale sa zajednicom čujućih i čujućim osobama. Međutim, u narednom istraživanju (Bat-Chava, 2000) nije utvrđena značajna povezanost između vrste identiteta i samopoštovanja, iako su osobe s gluhim i dvokulturnim identitetom postigle nešto više rezultate. Häfele je (2001, prema Hintermair, 2008) utvrdila značajnu pozitivnu povezanost samopoštovanja i dvokulturnog identiteta te negativnu povezanost marginalnog identiteta i samopoštovanja, dok čujući i gluhi identitet nisu bili značajno povezani. MaxwellMcCaw (2001) utvrdila je najnižu razinu samopoštovanja kod osoba s marginalnim identitetom, potom slijede, redom, osobe s čujućim, gluhim i dvokulturnim identitetom. Razlike između osoba s marginalnim i čujućim identitetom u odnosu na preostale tri skupine bile su značajne. Razlike između gluhog i dvokulturnog identiteta nisu bile značajne. Hintermair je pak (2008) utvrdio da najviše samopoštovanje imaju osobe $s$ dvokulturnim identitetom, a potom slijede, redom, osobe $s$ čujućim, gluhim i marginalnim identitetom. Značajne razlike utvrđene su između osoba s marginalnim identitetom i preostalih triju skupina te između osoba $s$ dvokulturnim i gluhim identitetom. Između osoba s dvokulturnim i čujućim identitetom te između osoba s čujućim i gluhim identitetom razlike nisu bile značajne. Meyer i Kashubeck-West (2011) nisu utvrdile povezanost između vrste identiteta i samopoštovanja, međutim u tom je istraživanju sudjelovao svega 21 sudionik.

Iako su rezultati spomenutih istraživanja nekonzistentni, ipak se može uočiti tendencija da najnižu razinu samopoštovanja imaju osobe s marginalnim identitetom, a najvišu osobe s dvokulturnim identitetom. Osjećaj pripadnosti objema zajednicama, komforno korištenje obaju jezika i sudjelovanje u društvenim aktivnostima obiju zajednica pozitivno se odražava na samopoštovanje gluhih i nagluhih osoba. S druge strane, više samopoštovanje osobu čini otpornijom na frustracije i, moguće, ustrajnijom u naporima da udovolji zahtjevima funkcioniranja u dvjema kulturama. 


\subsection{Kulturni identitet $\mathrm{i}$ zadovoljstvo životom}

Samopoštovanje je globalno vrednovanje sebe, a zadovoljstvo životom jest kognitivno vrednovanje vlastitog života na temelju vlastitih individualnih kriterija, odnosno standarda (Diener i Diener, 1995). Zadovoljstvo životom pokazatelj je kvalitete života, smatra se spoznajnom komponentom subjektivne dobrobiti (engl. subjective well-being) te odražava (ne)ravnotežu između težnji i trenutačnoga položaja pojedinca. Relativno je stabilno kroz vrijeme, iako na procjene često utječe trenutačno raspoloženje pojedinca i njegovi životni uvjeti (Pavot i Diener, 1993).

Komponente "dobrog života" najčešće uključuju zdravlje, uspješne odnose, postignuća u poslu ili školi, zaposlenje i materijalno blagostanje, no različite osobe imaju različite standarde "uspješnosti" glede tih komponenata pa se u istraživanjima kao mjera najčešće uzima globalna procjena zadovoljstva životom, umjesto zasebnih procjena po komponentama, odnosno domenama (Pavot i Diener, 1993). Bračni status i zdravlje imaju uglavnom pozitivne korelacije sa zadovoljstvom životom, dok povezanost s dobi i spolom nije utvrđena (Pavot i Diener, 1993). Prema nekim autorima (Diener i Diener, 1995) visoko samopoštovanje najsnažniji je prediktor zadovoljstva životom.

Malobrojna su istraživanja ispitivala zadovoljstvo životom u gluhih i nagluhih osoba. Istraživanjem provedenim na gluhim i nagluhim učenicima u dobi od osam do 18 godina, Gilman i suradnici (2004) utvrdili su značajno nižu razinu zadovoljstva životom kod slušnooštećenih učenika u odnosu na njihove čujuće vršnjake, i to glede globalne mjere zadovoljstva životom, zadovoljstva roditeljima, prijateljima i životnom okolinom. Razlike glede zadovoljstva školom i samim sobom nisu bile značajne.

Rezultati istraživanja Maxwell-McCaw (2001) pokazali su najvišu razinu zadovoljstva životom kod osoba s gluhim i dvokulturnim identitetom, među kojima nije bilo značajnih razlika, potom kod sudionika s čujućim identitetom, a najnezadovoljnije životom bile su osobe $s$ marginalnim identitetom. Hintermair je (2008) također utvrdio da su najzadovoljnije životom bile osobe s dvokulturnim identitetom, potom, redom, osobe s gluhim, čujućim te marginalnim identitetom. Značajne razlike utvrđene su između osoba s marginalnim identitetom i preostalih triju skupina te između osoba s čujućim i onih s dvokulturnim identitetom. Između osoba s gluhim i dvokulturnim identitetom nije bilo razlika. Istraživanje Meyer i Kashubeck-West (2011) nije pokazalo razlike u zadovoljstvu životom s obzirom na kulturni identitet, međutim ovdje se radilo o ukupno 21 sudioniku, za razliku od prethodna dva istraživanja u kojima su uzorci bili veliki. 
Ovi su rezultati, kao i rezultati istraživanja relacije samopoštovanja i kulturnog identiteta, nekonzistentni, ali ponovo ukazuju na tendenciju da najviše dobrobiti osobama donosi dvokulturni identitet, a najmanje marginalni. Slaba ovladanost govornim jezikom, uz istovremeno nepoznavanje znakovnog jezika i nepripadnost zajednici gluhih, predstavlja rizik za emocionalno zdravlje i socijalno funkcioniranje, odnosno grupnu identifikaciju prelingvalno gluhih i nagluhih osoba.

\subsection{Kulturni identitet i psihičko zdravlje}

Istraživanja povezanosti kulturnog identiteta i psihičkog zdravlja, odnosno psihosocijalnih teškoća u gluhih i nagluhih osoba, nisu do sada provedena, već posredno, na temelju rezultata istraživanja povezanosti demografskih varijabli za koje znamo da su povezane i s formiranjem identiteta i sa psihičkim zdravljem, možemo stvoriti neke pretpostavke.

Istraživanja pokazuju da su psihosocijalne teškoće češće u gluhe nego u čujuće djece (Hintermair, 2007; Fellinger, 2012), odnosno da je u odraslih gluhih prisutna visoka stopa tih teškoća (Van Gent i sur., 2012). Prema nekim istraživanjima postlingvalno gluhi imaju više simptoma teškoća od prelingvalno gluhih osoba (De Graaf i Bijl, 2002). Simptoma depresije i anksioznosti više je u gluhih nego u čujućih pojedinaca (Kvam i sur., 2007). Gluhe osobe više su izložene stresu te imaju više psihosomatskih poremećaja od čujućih osoba (Fellinger i sur., 2004). U populaciji gluhih zabilježena je veća učestalost posttraumatskog stresnog poremećaja (Black i Glickman, 2006).

U nekim istraživanjima utvrđeno je manje psihosocijalnih teškoća kod gluhe i nagluhe djece iz redovnih škola (Keilmann i sur., 2007; Van Gent i sur., 2007) negoli kod polaznika posebne škole, dok u drugima nisu utvrđene razlike (Fellinger i sur., 2009).

Kod djece kod koje je prisutna visoka razina ovladanosti znakovnim i govornim jezikom nije uočena veća učestalost psihosocijalnih poteškoća od one u njihovih čujućih vršnjaka (Sinkkonen, 1994; Polat, 2003). Djeca koja ne mogu uspješno komunicirati s okolinom, posebno s članovima obitelji i vršnjacima, četiri su puta više pogođena teškoćama u psihičkom zdravlju te su česte žrtve zlostavljanja. U gluhe djece iz obitelji u kojima se u komunikaciji koristi znakovni jezik primijećeni su razvijeni psihološki resursi i veće zadovoljstvo životom (Fellinger, 2012).

Pripadnici zajednice gluhih fluentno i komforno komuniciraju znakovnim jezikom. Društvene norme zajednice gluhih cijene privrženost zajednici, dijeljenje 
informacija i pružanje podrške (Lane i sur., 1996) te je stoga opravdano pretpostaviti da akulturacija u kulturu Gluhih djeluje kao zaštitni faktor za psihičko zdravlje prelingvalno gluhih i nagluhih osoba.

\section{PROBLEM I CILJ ISTRAŽIVANJA}

Dosadašnjim istraživanjima utvrđena je povezanost samopoštovanja i zadovoljstva životom s vrstom kulturnog identiteta. Iako rezultati nisu sasvim konzistentni, zamjetna je tendencija da najviše rezultate na ovim varijablama postižu gluhe i nagluhe osobe s dvokulturnim identitetom, a najniže one s marginalnim identitetom. Budući da ne raspolažemo nikakvim informacijama o ovim relacijama u gluhih i nagluhih osoba u Hrvatskoj, jer one do sada nisu bile ispitivane, ovim smo istraživanjem željeli steći uvid u korelate kulturnog identiteta gluhih i nagluhih osoba $\mathrm{u}$ nas te dobivene rezultate usporediti s inozemnima. Također, iako su dosadašnjim istraživanjima ispitivani pojedini aspekti psihičkog zdravlja u gluhe djece i odraslih, kako u svijetu, tako i u nas (Kuhn, 2012), nedostaju podaci o relacijama kulturnog identiteta i mjera psihičkog zdravlja (osim u dijelu koji se odnosi na samopoštovanje).

Nadalje, dosadašnjim istraživanjima nije bila ispitana povezanost pojedinih sastavnica kulturnog identiteta i mjera dobrobiti. Ako su dvokulturni i marginalni identitet povezani sa samopoštovanjem, zadovoljstvom životom i, moguće, psihičkim zdravljem, koje su od sastavnica kulturnog identiteta i na koji način povezane $s$ tim varijablama?

Cilj ovog istraživanja bio je ispitati povezanost sastavnica kulturnog identiteta (kulturne identifikacije, kulturnih sklonosti, sudjelovanja u kulturi, kulturnih znanja i jezične kompetencije) te vrste kulturnog identiteta (čujući, marginalni, gluhi i dvokulturni) s mjerama samopoštovanja, zadovoljstva životom i psihičkog zdravlja u gluhih i nagluhih osoba u Hrvatskoj.

\section{HIPOTEZE}

Na temelju rezultata dosadašnjih istraživanja moguće je postaviti sljedeće hipoteze: H1 - Identifikacija s kulturom Gluhih pozitivno je povezana sa samopoštovanjem, zadovoljstvom životom i psihičkim zdravljem gluhih i nagluhih osoba. 
H2 - Ovladanost znakovnim i govornim jezikom pozitivno je povezana sa samopoštovanjem, zadovoljstvom životom i psihičkim zdravljem gluhih i nagluhih osoba.

H3 - Gluhe i nagluhe osobe $s$ dvokulturnim identitetom imaju značajno više samopoštovanja i zadovoljstva životom te manje teškoća sa psihičkim zdravljem od osoba s marginalnim identitetom.

\section{METODE RADA}

\subsection{Uzorak sudionika}

U istraživanju su sudjelovale 443 gluhe i nagluhe osobe iz 17 gradova Hrvatske (od ukupno 23 grada u kojima postoje lokalne udruge gluhih i nagluhih): Zagreb, Krapina, Sisak, Karlovac, Rijeka, Pula, Šibenik, Vodice, Zadar, Split, Dubrovnik, Varaždin, Osijek, Našice, Nova Gradiška, Vinkovci i Požega. S obzirom na stupanj oštećenja sluha, u uzorku je bilo najviše gluhih osoba $(56 \%, \mathrm{~N}=256)$, zatim približno podjednak broj umjereno $(13 \%, \mathrm{~N}=57)$ i teško nagluhih $(15 \%$, $\mathrm{N}=69)$, a znatno je manje lako nagluhih ispitanika $(7 \%, \mathrm{~N}=31)$. Također, 30 ispitanika imalo je umjetnu pužnicu (7\%), a njih osam (2\%) odbacilo je umjetnu pužnicu. U cijelome uzorku neznatno je više zastupljeno osoba muškog spola $(51 \%, \mathrm{~N}=226) \mathrm{u}$ odnosu na ženski spol $(49 \%, \mathrm{~N}=217)$. Ukupni raspon kronološke dobi sudionika kreće se od 18 do 87 godina $(x=47 ; S D=16)$. Najviše je sudionika u dobi iznad 51 godine (44\%) te između 36 i 50 godina (29\%), dok je u dobi od 26 do 35 godina 19\% sudionika. Najmanje ih je između 18 i 25 godina (9\%). Vrijeme nastanka oštećenja sluha kreće se od rođenja do 38 godina. Prosječna dob nastanka oštećenja sluha iznosi oko dvije godine, odnosno 26 mjeseci. S obzirom na bračno stanje, najviše je oženjenih/udanih osoba (51\%); neoženjenih/neudanih je 20\%, $8 \%$ njih su udovci/udovice ili rastavljeni, a $12 \%$ ih je u vezi. Što se tiče stručne spreme, $83 \%$ sudionika ima srednju stručnu spremu, $7 \%$ njih ima visoku stručnu spremu, $5 \%$ sudionika ima višu stručnu spremu, 5\% ima završenu osnovnu školu, a tri sudionika (1\%) nisu završila nikakvu školu. S obzirom na vrstu završene osnovne škole, gotovo polovica sudionika (44\%) završila je posebnu školu s totalnim pristupom u komunikaciji; redovnu školu završilo je 38\% sudionika, dok je 16\% njih završilo posebnu školu 
s oralnim pristupom. Ukupno je, dakle, 55\% sudionika pohađalo škole u kojima se komuniciralo isključivo govornim jezikom, bez upotrebe manualnih oblika komunikacije. Polovica sudionika (50\%) ima završenu redovnu strukovnu školu; nešto više od trećine (39\%) pohađalo je posebnu srednju strukovnu školu s totalnim pristupom. Svega $8 \%$ njih završilo je gimnaziju. Višu školu završilo je $5 \%$ sudionika, a fakultet $7 \%$, dakle, vrlo mali broj sudionika. Ukupno 58\% sudionika pohađalo je redovne srednje škole. Što se tiče dobi u kojoj su počeli učiti znakovni jezik, 4\% sudionika nikada ga nije učilo i ne zna znakovni jezik. Raspon dobi početka učenja znakovnog jezika kreće se od jedne do 66 godina. Prosječna dob početka učenja znakovnog jezika kod preostalih $96 \%$ sudionika je 12 godina $(\mathrm{SD}=10)$.

\subsection{Varijable i mjerni instrumenti}

U obradu podataka u ovom istraživanju uključene su sljedeće varijable:

- Samopoštovanje (Samop)

- Zadovoljstvo životom (Zadov)

- Psihičko zdravlje (PZ)

- Sastavnice kulturnog identiteta

- Identifikacija s kulturom Gluhih (Identitetg)

- Sudjelovanje u kulturi Gluhih (Sudjelovanjeg)

- Sklonosti prema kulturi Gluhih (Sklonostig)

- Znanja o kulturi Gluhih (Znanjeg)

- Jezična kompetencija u znakovnom jeziku (Jezikg)

- Identifikacija s kulturom čujućih (Identitetč)

- Sudjelovanje u kulturi čujućih (Sudjelovanječ)

- Sklonosti prema kulturi čujućih (Sklonostič)

- Znanja o kulturi čujućih (Znanječ)

- Jezična kompetencija u većinskom jeziku (Jezikč)

- Vrste kulturnog identiteta:

- čujući identitet

- gluhi identitet

- dvokulturni identitet

- marginalni identitet. 
Za prikupljanje podataka na navedenim varijablama korišteni su sljedeći mjerni instrumenti:

\section{Rosenbergova skala samopoštovanja (RSES - Rosenberg Self-Esteem Scale; Rosenberg, 1965)}

Ova skala mjeri globalnu vrijednosnu orijentaciju prema sebi, tj. što pojedinac misli o sebi kao ličnosti (Lacković-Grgin, 1994). Skala sadrži deset čestica, pet definiranih u pozitivnom i pet u negativnom smjeru (Tablica 1).

Tablica 1. Prikaz čestica Rosenbergove skale samopoštovanja

Table 1. Rosenberg self-esteem scale items

\begin{tabular}{|l|l|}
\hline Općenito govoreći, zadovoljan sam sobom. & SAMOP1 \\
\hline $\begin{array}{l}\text { Sposoban sam raditi i izvršavati zadatke podjednako uspješno kao i } \\
\text { većina drugih ljudi. }\end{array}$ & SAMOP5 \\
\hline Osjećam da sam isto toliko sposoban kao i većina ljudi. & SAMOP7 \\
\hline Osjećam da posjedujem niz vrijednih osobina. & SAMOP8 \\
\hline Mislim da vrijedim, barem koliko i drugi ljudi. & SAMOP10 \\
\hline Želio bih da imam više poštovanja prema samome sebi. & SAMOP2 \\
\hline Osjećam da nemam puno toga čime bih se mogao ponositi. & SAMOP3 \\
\hline Ponekad se osjećam potpuno beskorisno. & SAMOP4 \\
\hline S vremena na vrijeme osjećam da ništa ne vrijedim. & SAMOP6 \\
\hline Sve više dolazim do spoznaje da jako malo vrijedim. & SAMOP9 \\
\hline
\end{tabular}

Negativno usmjerene čestice obrnuto se boduju. Ukupan rezultat dobiva se zbrajanjem bodova na skali Likertovog tipa od pet stupnjeva ( 1 = uopće se ne slažem, 2 = uglavnom se ne slažem, 3 = niti se slažem niti se ne slažem, 4 = uglavnom se slažem i 5 = potpuno se slažem). Mogući raspon rezultata kreće se od deset do 50 bodova. Visok rezultat odražava visoko samopoštovanje. Primjenom na sudionicima iz naše sredine skala je pokazala dobru pouzdanost: koeficijenti unutarnje konzistencije (Cronbach alpha) kretali su se od 0,74 do 0,89 (Bezinović, 1988). Na uzorku ovog istraživanja utvrđen je koeficijent pouzdanosti od 0,78 (Tablica 4). 


\section{Skala zadovoljstva životom (SWLS - The Satisfaction With Life Scale; Diener i sur., 1985)}

Skala se sastoji od pet tvrdnji kojima se mjeri kognitivna procjena zadovoljstva životom (Tablica 2). Odgovori su na skali Likertovog tipa sa sedam stupnjeva: $1=$ uopće se ne slažem, 2 = ne slažem se, 3 = uglavnom se ne slažem, 4 = niti se slažem niti se ne slažem, $5=$ uglavnom se slažem, $6=$ slažem se, 7 = u potpunosti se slažem.

Ukupan rezultat zbroj je rezultata svih pet tvrdnji i označava globalno zadovoljstvo životom, pri čemu viši rezultat upućuje na veće zadovoljstvo. Najmanji mogući rezultat je pet, a najveći 35 . Koeficijenti unutarnje konzistencije izvorne skale kreću se od 0,78 do 0,89 (Pavot i Diener, 1993). U ovom istraživanju Cronbach alpha iznosi 0,84 (Tablica 4).

Tablica 2. Prikaz čestica Skale zadovoljstva životom

Table 2. The Satisfaction with life scale items

\begin{tabular}{|l|}
\hline Moj život je vrlo blizu onome što smatram idealnim. \\
\hline Moji životni uvjeti su odlični. \\
\hline Zadovoljan/a sam svojim životom. \\
\hline Do sada sam ostvario/la važne stvari u svom životu. \\
\hline Kada bih živio/la ispočetka ne bih gotovo ništa promijenio/la. \\
\hline
\end{tabular}

\section{Upitnik zdravlja SF-36 (SF-36 Health survey; Ware i Sherbourne, 1992)}

Upitnik predstavlja teorijski utemeljenu i empirijski provjerenu operacionalizaciju koncepata fizičkog i psihičkog zdravlja te dviju njegovih općenitih manifestacija - funkcioniranja i dobrobiti (Ware i sur., 2003). Iz ovog upitnika, koji inače sadrži osam skala za mjerenje fizičkog i psihičkog zdravlja, u ovom istraživanju korištene su četiri skale (Tablica 3) čiji ukupan rezultat predstavlja mjeru psihičkog zdravlja sudionika:

1. RE - ograničenja u ostvarenju životnih uloga zbog emocionalnih problema koja mjere čestice SF6 - (3 čestice)

2. SF - socijalno funkcioniranje koje mjere čestice SF7 - (1 čestica)

3. PZ - psihičko zdravlje (psihički nemir i psihološka dobrobit) koje mjere čestice SF10 - (5 čestica)

4. VT - vitalnost i energija/umor koju mjere čestice SF11 - (4 čestice). 
Na skali RE mogući odgovori su $\mathrm{Da}$ (1 bod) ili $\mathrm{Ne}$ (2 boda). Na skali SF odgovori su na skali Likertovog tipa od pet stupnjeva: 1 = uopće ne, $2=$ malo, $3=$ umjereno, $4=$ prilično, 5 = izrazito. Na skalama PZ i VT odgovori su na skali Likertovog tipa od šest stupnjeva: 1 = nikada, 2 = rijetko, 3 = povremeno, 4 = dobar dio vremena, $5=$ skoro uvijek, 6 = stalno.

Ovisno o tvrdnji, bodovi su rekodirani kako bi viši rezultat na skali označavao bolje psihičko zdravlje. Najmanji mogući rezultat je 13, a najveći 65 .

Tablica 3. Prikaz čestica skala RE, SF, PZ i VT iz Upitnika zdravlja SF-36

Table 3. SF-36 items (subscales: Emotional role functioning, Social role functioning, Mental health, Vitality)

\begin{tabular}{|l|}
\hline RE - ograničenja zbog emocionalnih problema \\
\hline Skratili ste vrijeme provedeno u radu i drugim aktivnostima \\
\hline Obavili ste manje nego što ste željeli \\
\hline Niste obavili aktivnosti \\
\hline SF - socijalno funkcioniranje \\
\hline Fizičko zdravlje/emocionalni problem utjecali su na društvene aktivnosti \\
\hline PZ - psihičko zdravlje \\
\hline Bili ste nervozni \\
\hline Osjećali se potištenim \\
\hline Osjećali se spokojnim i mirnim \\
\hline Osjećali se malodušnim i tužnim \\
\hline Bili ste sretni \\
\hline VT - vitalnost i energija \\
\hline Bili puni energije \\
\hline Osjećali se iscrpljenim \\
\hline Osjećali se umornim \\
\hline Osjećali se puni života \\
\hline
\end{tabular}

U nekim ranijim istraživanjima na skalama za mjerenje psihičkog zdravlja Cronbach alpha iznosila je 0,88 (Velki, 2011). Na uzorku ovog istraživanja koeficijent unutarnje konzistencije iznosi zadovoljavajućih 0,81 (Tablica 4). 
Tablica 4. Pouzdanost Skala samopoštovanja, Zadovoljstva životom i Upitnika zdravlja na uzorku istraživanja

Table 4. Cronbach's Alpha for Rosenberg self-esteem scale, The Satisfaction with life scale and SF-36 subscales

\begin{tabular}{|l|c|}
\hline \multicolumn{1}{|c|}{ Skala } & Cronbach alpha $(\alpha)$ \\
\hline Rosenbergova skala samopoštovanja RSES & 0,78 \\
\hline Skala zadovoljstvom životom & 0,84 \\
\hline Upitnik zdravlja SF-36 & 0,81 \\
\hline
\end{tabular}

4. Akulturacijska skala (DAS - Deaf Acculturation Scale; Maxwell-McCaw i Zea, 2011)

Kulturni identitet ispitan je Skalom akulturacije gluhih, koja je uz dopuštenje autora prevedena na hrvatski jezik i kulturološki prilagođena gluhim i nagluhim osobama u Hrvatskoj.

Upitnik sačinjavaju dvije skale (Prilog 1) od ukupno 58 čestica s odgovorima na Likertovoj skali od pet stupnjeva. Jedna skala mjeri stupanj akulturacije u kulturu gluhih (DASg), a druga akulturacije u kulturu čujućih (DASč). Svaka skala sadrži pet podskala - faktora akulturacije u jednu odnosno drugu kulturu, utvrđenih faktorskom analizom prilikom konstrukcije izvornog mjernog instrumenta (Maxwell-McCaw i Zea, 2011).

Podskala Kulturna identifikacija mjeri psihološku identifikaciju s gluhim odnosno čujućim osobama, korištenje naziva koje osoba koristi za označavanje sebe te razinu zadovoljstva pri sudjelovanju u jednoj odnosno drugoj zajednici.

Podskala Sudjelovanje u kulturi mjeri stupanj uključenosti u različite aktivnosti jedne odnosno druge kulture.

Podskalom Kulturne sklonosti mjere se preferencije u odnosu na prijatelje, bračne partnere, djecu, suradnike itd., s obzirom na njihov slušni status odnosno akulturaciju.

Podskalom Jezična kompetencija mjeri se samoprocjena ekspresivnih i receptivnih vještina u znakovnom jeziku te govorenom i pisanom jeziku.

Naposlijetku, podskala Kulturno znanje mjeri samoprocjenu informiranosti o jednoj odnosno drugoj kulturi.

Ukupan rezultat za cijelu skalu dobiva se zbrajanjem bodova na svakoj skali, koji se zatim dijeli s ukupnim brojem čestica kako bi se dobila srednja vrijednost. Ako je ukupan rezultat veći od medijana (u ovom slučaju tri boda) na DASč i niži od medijana (odnosno tri boda) na DASg, radi se o čujućoj akulturaciji. Ukupan rezultat niži od tri na objema skalama upućuje na marginalni identitet. Ukupan rezultat veći od tri na 
DASg i niži od tri na DASč ukazuje na akulturaciju u kulturu Gluhih. Naposljetku, ukupan rezultat veći od tri na obje skale ukazuje na dvokulturnu akulturaciju.

U izvornoj verziji mjernog instrumenta (Maxwell-McCaw i Zea, 2011) Cronbach alpha za skalu DASg iznosi 0,95 , a za pojedine njene podskale kreće se u rasponu od 0,84 do 0,92 . Na skali DASč Cronbach alpha iznosi 0,91 , a za pojedine njene podskale kreće se u rasponu od 0,71 do 0,85 .

Unutarnje su pouzdanosti svih skala i podskala na uzorku ovog istraživanja zadovoljavajuće (Tablica 5).

Tablica 5. Pouzdanost skala DASg i DASč i pripadajućih podskala na uzorku ovog istraživanja

Table 5. Cronbach's Alpha of the DAS subscales

\begin{tabular}{|l|c|}
\hline \multicolumn{1}{|c|}{ Skala } & Cronbach alpha $(\alpha)$ \\
\hline DASg (Akulturacija u kulturu Gluhih) & 0,73 \\
\hline Podskala Identifikacija s kulturom (Identitetg) & 0,76 \\
\hline Podskala Sudjelovanje u kulturi (Sudjelovanjeg) & 0,79 \\
\hline Podskala Kulturne sklonosti (Sklonostig) & 0,79 \\
\hline Podskala Kulturno znanje (Znanjeg) & 0,90 \\
\hline Podskala Jezična kompetencija (Jezikg) & 0,91 \\
\hline DASč (Akulturacija u kulturu čujućih) & 0,79 \\
\hline Podskala Identifikacija s kulturom (Identitetč) & 0,67 \\
\hline Podskala Sudjelovanje u kulturi (Sudjelovanječ) & 0,77 \\
\hline Podskala Kulturne sklonosti (Sklonostič) & 0,77 \\
\hline Podskala Kulturno znanje (Znanječ) & 0,83 \\
\hline Podskala Jezična kompetencija (Jezikč) & 0,90 \\
\hline
\end{tabular}

\subsection{Način prikupljanja podataka}

Sve postojeće udruge gluhih i nagluhih u Hrvatskoj bile su obaviještene o provođenju istraživanja te su pozvane na suradnju. Ispitivanje se provodilo individualno u organizaciji udruga, a provodila su ga najmanje dva ispitivača uz, prema želji, prevođenje čestica na hrvatski znakovni jezik. Prije početka ispitivanja svim sudionicima dane su upute u kojima se naglasila anonimnost, povjerljivost i dobrovoljnost sudjelovanja $\mathrm{u}$ istraživanju te im se na jednom primjeru pojasnio način ispunjavanja skala.

Sudionicima je podijeljen tekst informiranog pristanka na sudjelovanje $\mathrm{u}$ istraživanju, kojeg su zatim pročitali i potpisali. Svi upitnici bili su spojeni u jednu cjelinu, osim pristanka na sudjelovanje, kako bi se izbjeglo narušavanje anonimnosti. Ispitivanje je trajalo oko 45 minuta po sudioniku. 


\subsection{Metode obrade podataka}

Izračunati su osnovni statistički parametri: frekvencije, postoci, aritmetičke sredine, standardne devijacije, minimalni i maksimalni rezultat. Relacije među varijablama ispitane su regresijskom analizom i Kruskal-Wallisovim testom. Sve statističke obrade izvršene su u paketu IBM SPSS Statistics for Windows, 22.0.

\section{REZULTATI I DISKUSIJA}

\subsection{Osnovni statistički pokazatelji i korelacije}

U Tablici 6 prikazani su osnovni statistički pokazatelji.

Tablica 6. Osnovni statistički pokazatelji $(\mathrm{N}=433)$

Table 6. Descriptive statistics $(\mathrm{N}=433)$

\begin{tabular}{|l|c|c|c|c|}
\hline VARIJABLA & M & SD & MIN & MAX \\
\hline Samop & 38,08 & 6,55 & 17 & 50 \\
\hline Zadov & 23,82 & 6,41 & 5 & 35 \\
\hline PZ & 45,40 & 7,55 & 18 & 65 \\
\hline Idg & 21,26 & 3,58 & 6 & 25 \\
\hline Sudg & 18,65 & 5,67 & 6 & 30 \\
\hline Sklg & 24,56 & 5,89 & 7 & 35 \\
\hline Zng & 14,51 & 5,35 & 5 & 25 \\
\hline Jzkg & 23,77 & 5.65 & 6 & 30 \\
\hline Idč & 15,01 & 4,50 & 5 & 25 \\
\hline Sudč & 13,79 & 5,19 & 6 & 30 \\
\hline Sklč & 20,26 & 5,93 & 7 & 35 \\
\hline Znč & 15,47 & 4,79 & 5 & 25 \\
\hline Jzkč & 21,16 & 5,67 & 6 & 30 \\
\hline
\end{tabular}

Legenda: $\mathrm{M}$ = aritmetička sredina, $\mathrm{SD}$ = standardna devijacija, $\mathrm{MIN}$ = najmanji rezultat, $\mathrm{MAX}=$ najveći rezultat

Legend: $\mathrm{M}=$ arithmetic mean, $\mathrm{SD}=$ standard deviation; $\mathrm{MIN}=$ minimum result, $\mathrm{MAX}=$ maximum result 
Utvrđene su (Tablica 7) značajne pozitivne korelacije između varijabli samopoštovanja, zadovoljstva životom i psihičkoga zdravlja, koje se kreću između $r=0,27^{* *}$ (samopoštovanje i zadovoljstvo životom) i $r=0,47^{* *}$ (samopoštovanje $\mathrm{i}$ psihičko zdravlje). Korelacija između zadovoljstva životom i psihičkog zdravlja iznosi $r=0,30^{* *}$. Samopoštovanje značajno nisko pozitivno korelira $s$ identifikacijom $s$ kulturom Gluhih (Identitetg, $r=0,17^{* *}$ ) i razinom ovladanosti znakovnim jezikom (Jezikg, $r=0,20^{* *}$ ). Također, značajno nisko negativno korelira i s varijablom Sklonostič $\left(r=-0,15^{* *}\right)$ te nisko pozitivno s varijablama Znanječ $\left(r=0,20^{* *}\right)$ i Jezikč $\left(\mathrm{r}=0,13^{* *}\right)$. Zadovoljstvo životom nisko pozitivno korelira $s$ varijablama Identitetg $\left(\mathrm{r}=0,15^{* *}\right)$ i Znanjeg $\left(\mathrm{r}=0,19^{* *}\right)$ te Identitetč $\left(\mathrm{r}=0,15^{* *}\right)$, Sudjelovanječ $\left(\mathrm{r}=0,15^{* *}\right)$, Sklonostič $\left(\mathrm{r}=0,14^{* *}\right)$ i Jezikč $\left(\mathrm{r}=0,16^{* *}\right)$. Psihičko zdravlje pozitivno nisko korelira $s$ varijablama Identitetg $\left(r=0,15^{* *}\right)$, Jezikg $\left(r=0,11^{* *}\right)$ te Znanječ $\left(\mathrm{r}=0,15^{* *}\right)$.

Tablica 7. Korelacije

Table $7 . \quad$ Correlations

\begin{tabular}{|l|c|c|c|c|c|c|c|c|c|c|c|c|}
\hline & SAMOP & ZADOV & PZ & Idg & Sudg & Sklg & Zng & Jzkg & Idč & Sudč & Sklč & Znč \\
\hline SAMOP & 1 & & & & & & & & & & & \\
\hline ZADOV & $0,268^{* *}$ & 1 & & & & & & & & & & \\
\hline PZ & $0,446^{* *}$ & $0,303^{* *}$ & 1 & & & & & & & & & \\
\hline Idg & $0,174^{* *}$ & $0,146^{* *}$ & $0,146^{* *}$ & 1 & & & & & & & & \\
\hline Sudg & 0,085 & 0,105 & 0,081 & $0,318^{* *}$ & 1 & & & & & & & \\
\hline Sklg & $-0,018$ & $-0,013$ & 0,001 & $0,567^{* *}$ & $0,356^{* *}$ & 1 & & & & & & \\
\hline Zng & 0,005 & $0,194^{* *}$ & 0,055 & $0,156^{* *}$ & $0,467^{* *}$ & $0,227^{* *}$ & 1 & & & & & \\
\hline Izkg & $0,195^{* *}$ & 0,034 & $0,114^{* *}$ & $0,387^{* *}$ & $0,357^{* *}$ & $0,460^{* *}$ & $0,311^{* *}$ & 1 & & & & \\
\hline Idč & $-0,040$ & $0,145^{* *}$ & $-0,015$ & $-0,280^{* *}$ & $-0,056$ & $-0,393^{* *}$ & $-0,011$ & $-0,187^{* *}$ & 1 & & & \\
\hline Sudč & 0,061 & $0,152^{* *}$ & 0,072 & $-0,216^{* *}$ & $0,225^{* *}$ & $-0,366^{* *}$ & 0,096 & $-0,114^{* *}$ & $0,578^{* *}$ & & & \\
\hline Sklč & $-0,152^{* *}$ & $0,140^{* *}$ & $-0,045$ & $-0,381^{* *}$ & $-0,082$ & $-0,419^{* *}$ & 0,090 & $-0,273^{* *}$ & $0,587^{* *}$ & $0,509^{* *}$ & 1 & \\
\hline Znč & $0,199^{* *}$ & 0,082 & $0,151^{* *}$ & $-0,057$ & $0,213^{* *}$ & $-0,140^{* *}$ & $0,375^{* *}$ & 0,040 & $0,220^{* *}$ & $0,393^{* *}$ & $0,293^{* *}$ & 1 \\
\hline Izkč & $0,126^{* *}$ & $0,156^{* *}$ & 0,079 & $-0,180^{* *}$ & $0,201^{* *}$ & $-0,269^{* *}$ & $0,281^{* *}$ & 0,012 & $0,398^{* *}$ & $0,411^{* *}$ & $0,433^{* *}$ & $0,519^{* *}$ \\
\hline
\end{tabular}

$* \mathrm{p}<0,01 ; * * \mathrm{p}<0,05$ 
Koliko se na temelju poznavanja obilježja sastavnica kulturnog identiteta može predviđati samopoštovanje, zadovoljstvo životom i psihičko zdravlje gluhih i nagluhih osoba pokušali smo utvrditi regresijskom analizom (Tablice 8 i 9).

\subsection{Sastavnice kulturnog identiteta i samopoštovanje}

Rezultati pokazuju da se na temelju poznavanja kulturalnih stavova i kompetencija gluhih i nagluhih osoba može predviđati njihovo samopoštovanje. Sastavnice akulturacije u kulturu Gluhih odnosno čujućih objašnjavaju (Tablica 8) oko 17\% varijance samopoštovanja $(\mathrm{R}=0,412 ; \mathrm{p}<0,000)$.

\subsubsection{Akulturacija u kulturu Gluhih i samopoštovanje}

Glede akulturacije u kulturu Gluhih, značajnim pojedinačnim prediktorima samopoštovanja (Tablica 9) pokazali su se identifikacija s kulturom Glubih (Identitetg, $\beta=0,191 ; \mathrm{p}=0,001$ ) i znanje znakovnog jezika (Jezikg, $\beta=0,188 ; \mathrm{p}=0,000$ ), koji pozitivno koreliraju sa samopoštovanjem, te sklonost kulturi Gluhih (Sklonostig, $\beta=-0,200 ; \mathrm{p}=0,002)$ i znanje o kulturi Gluhih (Znanjeg, $\beta=-128 ; \mathrm{p}=0,020$ ), koji negativno koreliraju sa samopoštovanjem.

Tvrdnje koje opisuju identifikaciju sa zajednicom gluhih (Prilog 1) su: Sebe nazivam Gluhim. Ugodno se osjećam u društvu gluhih. Osjećam da sam dio svijeta gluhih. Moj identitet gluhe osobe važan je dio onoga što jesam. Važan dio mog života je sudjelovanje u svijetu gluhih i druženje s gluhima. Osobe koje prihvaćaju svoje oštećenje sluha, koje su dobro integrirane u zajednicu gluhih i prihvaćaju druge gluhe i nagluhe osobe, tendiraju višem samopoštovanju.

Znanje znakovnog jezika opisuju tvrdnje koje se odnose na samoprocjenu receptivnih i ekspresivnih vještina u znakovnom jeziku i korištenja ručnih abeceda te poznavanje žargona u HZJ-u. Ovo istraživanje pokazuje da osobe koje imaju razvijene ove vještine tendiraju i višem samopoštovanju. Dobra ovladanost manualnim oblicima komunikacije u gluhih i nagluhih osoba osigurava im uspostavljanje sigurne privrženosti s drugima, kvalitetan pristup informacijama u različitim društvenim kontekstima i manju izloženost frustracijama i doživljajima neuspjeha, koji nerijetko prate njihovu komunikaciju govornim jezikom, a koji nepovoljno utječu na samopoštovanje.

Sklonost kulturi Gluhih opisuju tvrdnje o preferiranom pohađanju škole za gluhe, preferiranju gluhe djece te preferiranim interakcijama $s$ gluhim osobama (bračnim partnerima, prijateljima, kolegama na poslu). Osobe koje preferiraju 
druženje $s$ drugim gluhim i nagluhim osobama tendiraju nižem samopoštovanju. Kako je slična povezanost utvrđena i u odnosu na sklonost prema kulturi čujućih, ovaj nalaz detaljnije ćemo elaborirati kasnije.

Znanja o kulturi Gluhih opisuju tvrdnje koje se odnose na poznavanje običaja, važnih događaja, osoba i organizacija u kulturi Gluhih. Kulturološki osvještenije i bolje informirane gluhe i nagluhe osobe imaju bolji uvid u to koliki su napredak postigle zajednice gluhih $\mathrm{u}$ drugim zemljama svijeta, ponajprije u SAD-u i skandinavskim zemljama, glede svog statusa, statusa znakovnog jezika i uvjeta odgoja i obrazovanja gluhe djece. Zbog bolje informiranosti i svijesti o stvarnim potencijalima gluhih i nagluhih osoba s jedne strane, i svijesti o društvenim ograničenjima koja onemogućavaju ostvarivanje njihovih potencijala u njihovom aktualnom društvenom kontekstu s druge strane, moguće je da su ove osobe nezadovoljnije sobom. Nesrazmjer između realne i idealne slike doprinosi nižem samopoštovanju (Mann i sur., 2004).

\subsubsection{Akulturacija u kulturu čujućih i samopoštovanje}

I neke komponente akulturacije u kulturu čujućih pokazale su se pojedinačno značajnim prediktorima samopoštovanja: znanje jezika čujuće zajednice (Jezikč, $\beta=0,118 ; \mathrm{p}=0,043$ ) i znanje o kulturi čujućih (Znanječ, $\beta=0,211 ; \mathrm{p}=0,000$ ), koji pozitivno koreliraju sa samopoštovanjem, te sklonosti kulturi čujućih (Sklonostič, $\beta=-0,233 ; \mathrm{p}=0,000)$, koja negativno korelira sa samopoštovanjem.

Znanje jezika čujuće zajednice opisuju tvrdnje u odnosu na samoprocjenu receptivnih i ekspresivnih vještina u govornom i pisanom jeziku te poznavanje žargona u većinskom jeziku. Gluhe i nagluhe osobe koje bolje vladaju jezikom čujuće zajednice manje su izložene frustracijama zbog teškoća u komunikaciji i neovisnije su u svom svakodnevnom funkcioniranju, što se povoljno odražava na njihovo samopoštovanje. Dobro vladanje većinskim jezikom zaštitni je čimbenik za emocionalno funkcioniranje gluhih i nagluhih osoba (Ivasović, 2014). Međutim, budući da se ovdje radi o samopercepciji jezične kompetencije, moguće je da osobe s višim samopoštovanjem više vrednuju svoju jezičnu kompetenciju.

Gluhe i nagluhe osobe koje imaju više kulturalnih znanja vezanih uz čujuću zajednicu (događaji u hrvatskoj/svjetskoj povijesti, imena hrvatskih čujućih junaka, imena popularnih časopisa i novina, slavnih čujućih glumica i glumaca, političkih vođa) tendiraju višem samopoštovanju. Viša razina kulturalnih znanja o većinskoj zajednici, naročito glede običaja i vrijednosti, pripadnicima manjina olakšava 
snalaženje u većinskoj zajednici i općenito omogućava uspješnije društveno funkcioniranje i zadovoljavanje različitih potreba te bolju prihvaćenost od strane većinske zajednice, što sve zajedno povoljno utječe na samopoštovanje pojedinca. Čini se da su varijable koje u upitniku DAS reprezentiraju kulturalna znanja glede kulture čujućih u značajnoj mjeri povezane s razinom pismenosti gluhih i nagluhih osoba te dijelom sigurno mjere i jezičnu kompetenciju, za koju smo ranije ustvrdili da je povezana sa samopoštovanjem.

Također, gluhe i nagluhe osobe koje imaju izraženije sklonosti prema kulturi čujućih (žele čujućeg partnera, suradnike na radnom mjestu itd.) tendiraju nižem samopoštovanju. Zanimljivo je da je i preferiranje kulture Gluhih i preferiranje kulture čujućih pokazalo negativnu povezanost sa samopoštovanjem. Preferencija kao pojam uvijek u manjoj ili većoj mjeri podrazumijeva i isključivanje nekog drugog entiteta. Izraženija sklonost isključivanju pripadnika druge kulturne zajednice povezana je s nižim samopoštovanjem. Osobe koje naglašeno preferiraju svoju kulturnu zajednicu moguće to čine jer se osjećaju komunikacijski, jezično i uopće kulturno nekompetentnima glede funkcioniranja u drugoj kulturi, a svoju kompetentnost za funkcioniranje u tim zajednicama vrednuju nisko, što postaje čimbenikom njihova nižeg samopoštovanja. Posebno među osobama s gluhim i, naročito, radikalno gluhim identitetom, sklonost drugih gluhih i nagluhih osoba prema čujućoj kulturi smatra se nepoželjnom te takve gluhe i nagluhe osobe mogu biti slabije prihvaćene u zajednici gluhih, što se također može nepovoljno odražavati na njihovo samopoštovanje.

\subsection{Sastavnice kulturnog identiteta i zadovoljstvo životom}

Podskale DAS-a (Tablica 8) objašnjavaju $11 \%$ varijance zadovoljstva životom $(\mathrm{R}=0,336 ; \mathrm{p}<0,000)$. Pojedinačno značajni prediktori zadovoljstva životom (Tablica 9) su samo identifikacija s kulturom Gluhih (Identitetg, $\beta=0,262 ; \mathrm{p}=0,000$ ) i znanja o kulturi Gluhih (Znanjeg, $\beta=0,193 ; \mathrm{p}=0,001$ ), dok se ostale varijable akulturacije u kulturu Gluhih i kulturu čujućih nisu pokazale značajnim prediktorima.

Prihvaćanje svog oštećenja i zajednice gluhih kao preferirane zajednice, odnosno identificiranje s drugim gluhim i nagluhim osobama, omogućava ovim osobama ravnopravno, intenzivno i aktivno sudjelovanje u brojnim društvenim događanjima zajednice. U društvu sebi sličnih osoba, gluhe i nagluhe osobe dijele zajednička iskustva, frustracije i pobjede, ne doživljavaju svoje oštećenje sluha kao nedostatak te 
mnogi od njih žive vrlo ispunjen i sretan život. Zadovoljne su životom u svojoj zajednici.

Iako su se znanja o kulturi Gluhih pokazala negativno povezanima sa samopoštovanjem, čini se da je viša razina kulturalnih znanja povezana s višom razinom zadovoljstva životom. S jedne strane kulturalna su znanja povezana s osobnim (ne)zadovoljstvom, a s druge strane viša razina ovih znanja (vezanih uz zajednicu gluhih) zasigurno obogaćuje živote gluhih i nagluhih osoba. Neki od njih aktivno se bave umjetničkim (likovnim, scenskim, literarnim) stvaralaštvom, sudjeluju na međunarodnim festivalima kulture Gluhih na kojima stječu brojna nova međunarodna prijateljstva i poznanstva, šire svoje horizonte i pronalaze inspiraciju za svoj daljnji stvaralački rad, što sasvim sigurno doprinosi njihovom zadovoljstvu životom. Kako interpretacija rezultata ovog istraživanja odmiče, sve više postaje jasno kako bi za istraživanje kulturnog identiteta doista bila pogodnija kvalitativna metodologija i etnografski pristup $u$ istraživanju od kvantitativne metodologije (Hintermair, 2008).

\subsection{Sastavnice kulturnog identiteta i psihičko zdravlje}

Sa psihičkim zdravljem su nisko, ali značajno, pojedinačno povezani jedino prediktori: identifikacija s kulturom Gluhih (Identitetg, $\beta=0,180 ; \mathrm{p}=0,002$ ) i znanja o kulturi čujucih (Znanječ, $\beta=0,137 ; \mathrm{p}=0,021$ ), koji objašnjavaju ukupno 6,6\% varijance psihičkog zdravlja.

Osobe koje prihvaćaju svoje oštećenje, koje osjećaju pripadnost zajednici gluhih, odnosno identificiraju se s kulturom Gluhih, rjeđe se osjećaju nervoznima, potištenima, umornima i iscrpljenima, odnosno imaju manje emocionalnih teškoća. Grupna identifikacija predstavlja važan zaštitni čimbenik mentalnog zdravlja gluhih i nagluhih osoba (Ivasović, 2014).

Na temelju izloženih rezultata možemo konstatirati da se hipoteza $\mathrm{H} 1$ prihvaća: identifikacija s kulturom Gluhih pozitivno je povezana sa samopoštovanjem, zadovoljstvom životom i psihičkim zdravljem gluhih i nagluhih osoba, a hipoteza $\mathrm{H} 2$ djelomice se prihvaća: ovladanost znakovnim i govornim jezikom povezana je sa samopoštovanjem, ali ne i sa zadovoljstvom životom i psihičkim zdravljem gluhih i nagluhih osoba. 
Tablica 8. Regresijska analiza podskala DAS-a kao prediktora na kriterijske varijable samopoštovanja, zadovoljstva životom i psihičkog zdravlja $\left(\mathrm{R}, \mathrm{R}^{2}, \mathrm{~F}, \mathrm{p}\right)$

Table 8. Regression analysis of the DAS subscales as predictor variables for selfesteem, satisfaction with life and mental health as criterion variables $\left(\mathrm{R}, \mathrm{R}^{2}, \mathrm{~F}, \mathrm{p}\right)$

\begin{tabular}{|l|c|c|c|c|}
\hline & $\mathrm{R}$ & $\mathrm{R}^{2}$ & $\mathrm{~F}$ & $\mathrm{p}$ \\
\hline Samopoštovanje & 0,412 & 0,170 & 8,820 & 0,000 \\
\hline Zadovoljstvo životom & 0,336 & 0,113 & 5,485 & 0,000 \\
\hline Psihičko zdravlje & 0,257 & 0,066 & 3,056 & $\mathbf{0 , 0 0 1}$ \\
\hline
\end{tabular}

Tablica 9. Regresijska analiza podskala DAS-a kao prediktora na kriterijske varijable samopoštovanja, zadovoljstva životom i psihičkog zdravlja $(\beta, \mathrm{p})$

Table 9. Regression analysis of the DAS subscales as predictor variables for selfesteem, satisfaction with life and mental health as criterion variables $(\beta, p)$

\begin{tabular}{|l|c|c|c|c|c|c|}
\hline \multirow{2}{*}{ Kriteriji } & \multicolumn{2}{|c|}{ Samopoštovanje } & \multicolumn{2}{c|}{ Zadovoljstvo životom } & \multicolumn{2}{c|}{ Psihičko zdravlje } \\
\hline Prediktori & $\beta$ & $\mathrm{p}$ & $\beta$ & $\mathrm{p}$ & $\beta$ & $\mathrm{P}$ \\
\hline Identitetg & $\mathbf{0 , 1 9 1}$ & $\mathbf{0 , 0 0 1}$ & $\mathbf{0 , 2 6 2}$ & $\mathbf{0 , 0 0 0}$ & $\mathbf{0 , 1 8 0}$ & $\mathbf{0 , 0 0 2}$ \\
\hline Sudjelovanjeg & $-0,017$ & 0,766 & $-0,036$ & 0,547 & $-0,012$ & 0,843 \\
\hline Sklonostig & $-0,200$ & $\mathbf{0 , 0 0 2}$ & $-0,072$ & 0,271 & $-0,121$ & 0,073 \\
\hline Znanjeg & $-0,128$ & $\mathbf{0 , 0 2 0}$ & $\mathbf{0 , 1 9 3}$ & $\mathbf{0 , 0 0 1}$ & $-0,030$ & 0,606 \\
\hline Jezikg & $\mathbf{0 , 1 8 8}$ & $\mathbf{0 , 0 0 0}$ & $-0,032$ & 0,556 & 0,089 & 0,112 \\
\hline Identitetč & $-0,031$ & 0,613 & 0,070 & 0,268 & $-0,043$ & 0,504 \\
\hline Sudjelovanječ & 0,072 & 0,257 & 0,087 & 0,188 & 0,075 & 0,266 \\
\hline Sklonostič & $-0,233$ & $\mathbf{0 , 0 0 0}$ & 0,086 & 0,175 & $-0,068$ & 0,299 \\
\hline Znanječ & $\mathbf{0 , 2 1 1}$ & $\mathbf{0 , 0 0 0}$ & $-0,096$ & 0,096 & $\mathbf{0 , 1 3 7}$ & $\mathbf{0}, 021$ \\
\hline Jezikč & $\mathbf{0 , 1 1 8}$ & $\mathbf{0 , 0 4 3}$ & 0,086 & 0,151 & 0,033 & 0,588 \\
\hline
\end{tabular}




\subsection{Razlike u samopoštovanju, zadovoljstvu životom i psihičkom zdravlju gluhih i nagluhih osoba s obzirom na vrstu njihova kulturnog identiteta}

Detaljni podaci o zastupljenosti pojedine vrste identiteta, njihovim značajkama i relacijama s demografskim obilježjima gluhih i nagluhih osoba, prikazani su ranije u drugim radovima (Bradarić-Jončić i Möhr Nemčić, 2016; Möhr Nemčić i BradarićJončić, 2016). Ovdje ćemo samo podsjetiti da gotovo polovica sudionika (48\%) ima gluhi identitet; dvokulturni identitet ima 32\% sudionika, čujući identitet ima $12 \%$ sudionika, dok je u najmanjem postotku prisutan marginalni identitet (8\%), što su podaci vrlo slični onima iz istraživanja provedenih u SAD-u (Maxwell-McCaw, 2001) i Njemačkoj (Hintermair, 2008). Dakle, ukupno 80\% njih ima gluhi ili dvokulturni identitet, iako $58 \%$ njih tijekom školovanja nije dolazilo u doticaj sa znakovnim jezikom i samo 12\% njih ima gluhe roditelje (Möhr Nemčić i Bradarić-Jončić, 2016).

Tablica 10. Razlike među osobama $s$ različitim kulturnim identitetom u samopoštovanju, zadovoljstvu životom i psihičkom zdravlju

Table 10. Differences in self-esteem, satisfaction with life and mental health with regard to the type of cultural identity

\begin{tabular}{|c|c|c|c|c|c|c|}
\hline & Vrsta identiteta & $\mathrm{N}$ & Srednji rang & Hi-kvadrat & Stupnjevi slobode & $\mathrm{P}$ \\
\hline \multirow{5}{*}{ Psihičko zdravlje } & Čujući & 51 & 235,81 & \multirow{5}{*}{2,950} & \multirow{5}{*}{3} & \multirow{5}{*}{3,99} \\
\hline & Marginalni & 35 & 191,67 & & & \\
\hline & Gluhi & 215 & 219,68 & & & \\
\hline & Bikulturni & 142 & 228,03 & & & \\
\hline & Ukupno & 443 & & & & \\
\hline \multirow{5}{*}{$\begin{array}{l}\text { Zadovoljstvo } \\
\text { životom }\end{array}$} & Čujući & 51 & 205,89 & \multirow{5}{*}{9,012} & \multirow{5}{*}{3} & \multirow{5}{*}{0,027} \\
\hline & Marginalni & 35 & 187,20 & & & \\
\hline & Gluhi & 215 & 215,55 & & & \\
\hline & Bikulturni & 142 & 246,13 & & & \\
\hline & Ukupno & 443 & & & & \\
\hline \multirow{5}{*}{ Samopoštovanje } & Čujući & 51 & 232,45 & \multirow{5}{*}{3,749} & \multirow{5}{*}{3} & \multirow{5}{*}{0,290} \\
\hline & Marginalni & 35 & 184,73 & & & \\
\hline & Gluhi & 215 & 227,33 & & & \\
\hline & Bikulturni & 142 & 219,36 & & & \\
\hline & Ukupno & 443 & & & & \\
\hline
\end{tabular}


Budući da distribucija za varijablu gluhog identiteta nije bila normalna, razlike među sudionicima u samopoštovanju, zadovoljstvu životom i psihičkom zdravlju s obzirom na vrstu kulturnog identiteta ispitali smo Kruskal-Wallisovim testom (Tablica 10). Test pokazuje da među gluhim i nagluhim osobama različitog kulturnog identiteta razlika postoji jedino $u$ stupnju zadovoljstva životom, ali ne i samopoštovanju i psihičkom zdravlju. Uvidom u vrijednosti srednjih rangova vidljivo je da najviše zadovoljstva životom imaju osobe $s$ dvokulturnim, a najmanje osobe $s$ marginalnim identitetom te se hipoteza H3 djelomice prihvaća. Ovladanost obama jezicima i aktivno sudjelovanje u životima obiju zajednica koje im ta dvojezičnost omogućava, te osjećaj pripadnosti objema kulturama, gluhim i nagluhim osobama $s$ dvokulturnim identitetom pruža više životnog zadovoljstva od onoga u osoba s gluhim, čujućim i marginalnim identitetom. Naš je rezultat tek, dakle, djelomice u skladu s rezultatima prethodnih istraživanja (Maxwell-McCaw, 2001; Hintermair, 2008), u kojima je također utvrđena značajna razlika između osoba s dvokulturnim i marginalnim identitetom glede zadovoljstva životom, ali također i glede samopoštovanja, što $u$ našem istraživanju nije slučaj. Osobe $s$ marginalnim identitetom i u ovom su istraživanju postigle najniže rezultate na sve tri mjere dobrobiti, ali značajno samo na varijabli zadovoljstva životom. Ostale vrste identiteta, s obzirom na samopoštovanje i psihičko zdravlje, rangirane su na nekonzistentan način, pri čemu nešto bolje rezultate postižu gluhe i nagluhe osobe $s$ čujućim identitetom, ali ne značajno. Da je udio sudionika s čujućim i marginalnim identitetom bio veći, možda bi se pokazale i razlike u samopoštovanju, kao i u spomenutim istraživanjima.

\section{ZAKLJUČAK}

Rezultati ovog istraživanja ukazuju na značaj identifikacije gluhih i nagluhih osoba sa zajednicom odnosno kulturom Gluhih za dobrobit odnosno kvalitetu života ovih osoba. Osjećaj pripadnosti zajednici gluhih i čvrste veze $s$ drugim gluhim i nagluhim članovima zajednice pozitivno su povezani sa samopoštovanjem, zadovoljstvom životom i psihičkim zdravljem gluhih i nagluhih osoba. Dobra ovladanost znakovnim i govornim jezikom također doprinosi njihovom samopoštovanju. Osobe $s$ dvokulturnim identitetom, koje vladaju obama jezicima, osjećaju se prihvaćeno u objema zajednicama i aktivno sudjeluju u životima obiju zajednica, postižu višu razinu 
zadovoljstva životom od preostalih triju skupina s obzirom na vrstu kulturnog identiteta, posebno u odnosu na osobe s marginalnim identitetom.

Definiranje ciljeva odgoja, obrazovanja i rehabilitacije djece i mladeži oštećena sluha, pri kojem obično naglašavamo njihovu socijalnu integraciju, odnosno inkluziju u čujuću okolinu, kao opći i krajnji cilj našeg stručnog rada treba uzeti u obzir i potrebu gluhih i nagluhih osoba za integracijom i u zajednicu sebi sličnih osoba koje dijele zajednički jezik, običaje i vrijednosti, u kojoj se osjećaju sigurno i zaštićeno i u kojoj uspješno zadovoljavaju svoje komunikacijske, intelektualne, emocionalne i socijalne potrebe. Prepoznavši važnost identifikacije gluhih i nagluhih osoba za njihovo mentalno zdravlje i prije nego su se pojavila istraživanja kulturnog identiteta, programi dvojezičnog obrazovanja gluhe i nagluhe djece i mladeži naglašavaju od samih svojih početaka i izgradnju zdravog kulturnog identiteta, uz dobru ovladanost dvama jezicima, kao jedan od dva glavna cilja edukacije i rehabilitacije djece i mladeži u ovim programima (Neil Mahshie, 1995; Knight i Swanwick, 2002; Hintermair, 2014; Teruggi, 2014).

Buduća istraživanja trebala bi se usmjeriti posebno i na razvoj identiteta djece $\mathrm{i}$ mladeži s kohlearnim implantatima. Generacije rano implantirane djece i mladeži upravo stasaju i postavlja se pitanje kako će u funkciji vremena izgledati oblikovanje njihova identiteta. Može se pretpostaviti da će do dvadesetih godina svog života tendirati čujućem identitetu, no postavlja se pitanje hoće li, kao i generacije mnogih mladih gluhih koji su svoje obrazovanje proveli bez doticaja sa znakovnim jezikom, u nekom trenutku potražiti znakovni jezik i pristup zajednici gluhih i formirati dvokulturni ili čak gluhi identitet. Prilično je vjerojatno da će oni mladi gluhi koji unatoč ranoj implantaciji nisu uspjeli dobro ovladati hrvatskim jezikom to i učiniti. Longitudinalno praćenje dalo bi odgovore na ta pitanja.

Primjenom kvalitativne metodologije u budućim istraživanjima mogle bi se dobiti vrijedne informacije o čimbenicima i obilježjima kulturnog identiteta gluhih i nagluhih osoba.

Ograničenja ovog istraživanja leže u malom broju sudionika s čujućim i marginalnim identitetom, što je moglo utjecati na rezultate istraživanja, kao i velika heterogenost populacije gluhih i nagluhih osoba. Nadalje, upitnikom DAS mjere se samoprocjene jezične kompetencije i znanja o kulturi, te nam on time ne pruža pouzdane informacije o navedenim aspektima kulturnog identiteta, što ograničava mogućnost donošenja zaključaka o ispitivanim relacijama s varijablama dobrobiti. 


\section{REFERENCIJE}

Bat-Chava, Y. (1993). Antecedents of self-esteem in deaf people: A meta-analytical review. Rehabilitation Psychology 38, 4, 221-234.

Bat-Chava, Y. (1994). Group identification and self-esteem of deaf adults. Personality and Social Psychology Bulletin 20, 5, 494-502.

Bat-Chava, Y. (2000). Diversity of deaf identities. American Annals of the Deaf 145, 5, 420-428.

Bezinović, P. (1988). Percepcija osobne kompetentnosti kao dimenzija samopoimanja. Doktorska disertacija, Zagreb: Filozofski fakultet.

Black, P., Glickman, N. S. (2006). Demographics, psychiatric diagnoses and other characteristics of North American deaf and hard of hearing inpatiens. Journal of Deaf Studies and Deaf Education 11, 3, 303-321.

Bradarić-Jončić, S., Mohr Nemčić, R. (2016). Neka obilježja kulturnog identiteta gluhih i nagluhih osoba. Logopedija 6, 1, 24-37.

Cappelli, M., Daniels, T., Durieux Smith, A., McGrath, P., Neuss, D. (1995). Social development of children with hearing impairments who are integrated into general education classrooms. The Volta Review 97, 3, 197-208.

Cates, J. A. (1991). Self-concept in hearing and prelingual, profoundly deaf students. A comparison of teachers' perceptions. American Annals of the Deaf 136, 4, 354359.

Crowe, T. (2003). Self-esteem scores among deaf college students: An examination of gender and parents' hearing status and signing ability. Journal of Deaf Studies and Deaf Education 8, 2, 199-206.

De Graaf, R., Bijl, R. V. (2002). Determinants of mental stress in adults with a severe auditory impairment. Differences between prelingual and postlingual deafness. Psychosomatic Medicine 64, 1, 61-70.

Desselle, D. (1994). Self-esteem, family climate, and communiction patterns in relation to deafness. American Annals of the Deaf 139, 3, 322-328.

Diener, E., Diener, M. (1995). Cross-cultural correlates of life satisfaction and selfesteem. Journal of Personality and Social Psychology 68, 4, 653-663.

Diener, E., Emmons, R. A., Larsen, R. J., Griffin, S. (1985). The Satisfaction with Life Scale. Journal of Personality Assessment 49, 1, 71-75. 
Eriks-Brophy, A., Durieux-Smith, A., Olds, J., Fitzpatrick, E. M., Duquette, C. (2012). Communication, academic, and social skills of young adults with hearing loss. The Volta Review 112, 1, 5-35.

Erol, R. Y., Orth, U. (2011). Self-esteem development from age 14 to 30 years: A longitudinal study. Journal of Personality and Social Psychology 101, 3, 607-661.

Fellinger, J. (2012). Mental health of deaf people. The Lancet 379, 9820, 10371044.

Fellinger, J., Holzinger, D., Schoberberger, R., Lenz, G. (2004). Quality of life of deaf in Austria. U S. Bradarić-Jončić i V. Ivasović (ur.), Sign Language, Deaf Culture \& Bilingual Education, 195-202. Zagreb: Faculty of Education and Rehabilitation Sciences.

Fellinger, J., Holzinger, D., Sattel, H., Laucht, M., Goldberg, D. (2009). Correlates of mental health disorders among children with hearing impairments. Developmental Medicine and Child Neurology 51, 8, 635-641.

Gilman, R., Easterbrooks, S., Frey, M. (2004). A preliminary study of multidimensional life satisfaction reports among deaf/hard of hearing youth across environmental settings. Social Indicators Research 66, 1-2, 143-164.

Glickman, N. S., Carey, J. C. (1993). Measuring deaf cultural identities: A preliminary investigation. Rehabilitation Psychology 38, 4, 275-283.

Hintermair, M. (2007). Prevalence of socioemotional problems in deaf and hard of hearing children in Germany. American Annals of the Deaf 152, 3, 320-330.

Hintermair, M. (2008). Self-esteem and satisfaction with life of deaf and hard-ofhearing people - a resource-oriented approach to identity work. Journal of Deaf Studies and Deaf Education 13, 2, 278-300.

Hintermair, M. (2014). Psychosocial development of deaf and hard of hearing children in 21st century: Opportunities and challenges. U M. Marschark, G. Tang i H. Knoors (ur.): Bilingualism and Bilingual Deaf Education, 152-187. Oxford: University Press.

Ivasović, V. (2014). I ja želim znati! Gluhi i nagluhi učenik u redovnoj školi. Zagreb: Hrvatski savez gluhih i nagluhih.

Jambor, J., Elliot, M. (2005). Self-esteem and coping strategies among deaf students. Journal of Deaf Studies and Deaf Education 10, 1, 61-81.

Keilmann, A., Limberger, A., Mann, W. J. (2007). Psychological and physical wellbeing in hearing-impaired children. International Journal of Pediatric Otorhinolaryngology 71, 11, 1747-1752. 
Kluwin, T. N., Stinson, M. S., Colarossi, G. M. (2002). Social processes and outcomes of in-school contact between deaf and hearing peers. Journal of Deaf Studies and Deaf Education 7, 3, 200-213.

Knight, P., Swanwick, R. (2002). Working with Deaf Pupils. Sign Bilingual Policy into Practice. London: David Fulton Publishers.

Kuhn, N. (2012). Socio-emocionalne teškoće gluhe i nagluhe djece: Učestalost i obiteljski čimbenici. Neobjavljena doktorska disertacija, Zagreb: Edukacijskorehabilitacijski fakultet Sveučilišta u Zagrebu.

Kvam, M. H., Loeb, M., Tambs, K. (2007). Mental health in deaf adults: Symptoms of anxiety and depression among hearing and deaf individuals. Journal of Deaf Studies and Deaf Education 12, 1, 1-7.

Lacković-Grgin, K. (1994). Samopoimanje mladih. Jastrebarsko: Naklada Slap.

Lane, H., Hoffmeister, R., Bahan, B. (1996). A Journey into the Deaf-World. Dawn Sign Press, California.

Leigh, I. W. (1999). Inclusive education and personal development. Journal of Deaf Studies and Deaf Education 4, 3, 236-245.

Leigh, I. W. (2009). A Lens on Deaf Identities. Oxford: University Press.

Leigh, I. W., Maxwell-McCaw, D., Bat-Chava, Y., Christiansen, J. B. (2009). Correlates of psychosocial adjustment in deaf adolescents with and without cochlear implants: A preliminary investigation. Journal of Deaf Studies and Deaf Education 14, 2, 244-259.

Mann, M., Hosman, C. M. H., Schaalma, H. P., de Vries, N. K. (2004). Selfesteem in a broad-spectrum approach for mental health promotion. Health Education Resources 19, 4, 357-372.

Marschark, M., Tang, G., Knoors, H. (2014). Bilingualism and Bilingual Deaf Education. Oxford: University Press.

Maxwell-McCaw, D. (2001). Acculturation and psychological well-being in deaf and hard-of-hearing people. Neobjavljena doktorska disertacija, Washington, DC: George Washington University.

Maxwell-McCaw, D. L., Leigh, I. W., Marcus, A. (2000). Social identity in Deaf culture: A comparison of ideologies. Journal of the American Deafness and Rehabilitation Association 33, 14-27.

Maxwell-McCaw, D. L., Zea, M. C. (2011). The Deaf Acculturation Scale (DAS): Development and validation of a 58-item measure. Journal of Deaf Studies and Deaf Education 16, 3, 325-342. 
Mejstad, L., Heiling, K., Svedin, C. G. (2009). Mental health and self-image among deaf and hard of hearing children. American Annals of the Deaf 153, 5, 504-515.

Meyer, J., Kashubeck-West, S. (2011). Psychological well-being in emerging adults who are deaf. U D. H. Zand i K. J. Pierce (ur.), Reselience in Deaf Children: Adaptation Through Imerging Adulthood, 359-375. New York: Springer.

Möhr Nemčić, R., Bradarić-Jončić, S. (2016). Relacije kulturnog identiteta i nekih demografskih obilježja gluhih i nagluhih osoba. Hrvatska revija za rehabilitacijska istraživanja 52, 1, 63-77.

Neal Mahshie, Sh. (1995). Educating Deaf Children Bilingually: With Insights and Applications from Sweden and Denmark. Pre-College Programs, Washington, D. C.: Gallaudet University.

Obrzut, J. E., Maddock, G. J., Lee, C. P. (1999). Determinants of self-concept in deaf and hard of hearing children. Journal of Development and Physical Disabilities $11,3,237-251$.

Orth, U., Robins, R. W. (2014). The development of self-esteem. Current Directions in Psychological Science 23, 5, 381-387.

Pavot, W., Diener, E. (1993). Review of the Satisfaction with life scale. Psychological Assessment 5, 2, 164-172.

Percy-Smith, L., Cay-Thomasen, P., Gudman, M., Jensen, J., Thomsen, J. (2008). Self-esteem and social well-being of children with cochlear implant compared to normal-hearing children. International Journal of Pediatric Otorhinolaryngology 72, 7, 1113-1120.

Polat, F. (2003). Factors affecting psychosocial adjustment of deaf students. Journal of Deaf Studies and Deaf Education 8, 3, 325-339.

Rosenberg, M. (1965). Society and the Adolescent Self-Image. Princeton, New York: Princeton University Press.

Sinkkonen, J. (1994). Evaluation of mental health problems among Finnish hearing impaired children. Psychiatrica Fennica 25, 52-65.

Teruggi, L. A. (ur.) (2014). Jedna škola, dva jezika. Iskustvo dvojezičnosti u vrtiću i osnovnoj školi u Cossatu. Zagreb: Hrvatsko društvo tumača i prevoditelja znakovnog jezika gluhih i ERF.

Theunissen, S., Rieffe, C., Netten, A. P., Briaire, J. J., Soede, W., Kouwenberg, M., Frijns, J. (2014). Self-esteem in hearing-impaired children: The influence 
of communication, education, and audiological characteristics. PLOS ONE DOI: 10.1371/journal.pone.0094521 Aug 29, 2014.

Van Gent, T., Goedhart, A. W., Hindley, P. A., Treffers, P. D. (2007). Prevalence and correlates of psychopathology in a sample of deaf adolescents. Journal of Child Psychology and Psychiatry 48, 9, 950-958.

Van Gent, T., Goedhart, A. W., Knoors, H., Westenberg, P. M., Treffers, P. (2012). Self-concept and ego development in deaf adolescents: A comparative study. Journal of Deaf Studies and Deaf Education 17, 3, 333-351.

Van Gurp, S. (2001). Self-concept of deaf secondary school students in different educational settings. Journal of Deaf Studies and Deaf Education 6, 1, 55-69.

Velki, T. (2011). The correlation considering the degree of autonomous motivation, academic achievement and mental health. Croatian Journal of Education 13, 3, 56-87.

Ware, J. E. Jr., Sherbourne, C. D. (1992). The MOS 36-item short-form health survey (SF-36). Conceptual framework and item selection. Medical Care 30, 6, 473-483. 


\section{Renata Möhr Nemčić, Sandra Bradarić-Jončić}

sandra.bradaric-joncic@erf.hr

Faculty of Education and Rehabilitation Sciences, University of Zagreb

Croatia

\section{The relationship between cultural identity and self-esteem, satisfaction with life and psychological health in deaf and hard of hearing persons}

\section{Summary}

Although to a certain extent inconsistent, the results of the previous study suggest the relationship between cultural identity of the deaf and hard of hearing persons and their selfesteem and satisfaction with life. The aim of this study was to examine the relationship between self-esteem, satisfaction with life and psychological health and the components of the cultural identity (cultural identification, enjoyment in cultural activities, cultural preferences, cultural knowledge and language competence), as well as the type of the cultural identity of deaf and hard of hearing persons (hearing, marginal, deaf and bicultural). The research sample consisted of 443 deaf and hard of hearing persons, aged between 18 and 87 years, from 17 Croatian cities. The research was conducted using the DAS - Deaf Acculturation Scale (MaxwellMcCaw \& Zea, 2011), Rosenberg Self-Esteem Scale, Diener's Satisfaction With Life Scale, as well as 4 subscales of the SF-36 (The Short Form (36) Health Survey) measuring the psychological well-being. The data were analysed using the regression analysis and KruskalWallis $\mathrm{H}$ test. Identification with the Deaf culture proved to be a significant predictor of the self-esteem, life satisfaction and psychological health in deaf and hard of hearing persons. Language competences in both sign- and majority language also proved to be significant predictors of the self-esteem, next to the cultural knowledge related to both hearing and Deaf culture (the last being negatively related to self-esteem), as well as the cultural preferences for the Deaf and for the hearing culture (both negatively related to self-esteem). Following the identification with the Deaf culture, the satisfaction with life proved to be significantly predicted by cultural knowledge on the Deaf culture, and psychological health by cultural knowledge on the hearing culture. Significant differences between participants with different types of cultural identity were found only regarding their satisfaction with life: biculturally 
acculturated persons expressed the highest- and marginally acculturated persons the lowest level of life satisfaction. Marginally acculturated persons also achieved the lowest results on the self-esteem and psychological health measures, but these differences didn't prove to be significant.

Key words: cultural identity, Deaf culture, sign language, self-esteem, life satisfaction 


\section{PRILOG 1}

Prikaz čestica Upitnika DAS (Deaf Acculturation Scale)

Maxwell-McCaw i Zea, 2011.

DASg (Akulturacija u kulturu Gluhih) - podskala Identifikacija s kulturom Gluhih (Identitetg):

Sebe nazivam Gluhim.

Ugodno se osjećam u društvu gluhih.

Osjećam da sam dio svijeta gluhih.

Moj identitet gluhe osobe važan je dio onoga što jesam.

Važan dio mog života je sudjelovanje u svijetu gluhih i druženje s gluhima.

DASč (Akulturacija u kulturu čujućih) - podskala Identifikacija s kulturom čujućih (Identitetč):

Osjećam da sam dio čujućega svijeta.

Sebe nazivam nagluhim ili slušno oštećenim.

Važan dio moga života je sudjelovanje u svijetu čujućih i druženje s čujućima.

Osjećam se ugodno u društvu čujućih osoba.

Često želim da mogu bolje čuti ili postati čujuća osoba.

\section{DASg (Akulturacija u kulturu Gluhih) - podskala Sudjelovanje u kulturi Gluhih} (Sudjelovanjeg):

Koliko uživate ići na zabave/okupljanja gluhih?

Koliko uživate čitati časopise/knjige koje su napisali gluhi autori?

Koliko uživate gledati video-snimke na znakovnome jeziku u kojima gluhi pričaju priče?

Koliko uživate ići na kazališne predstave s gluhim glumcima/glumicama?

Koliko uživate sudjelovati u političkim aktivnostima za unapređenje prava gluhih?

Koliko uživate sudjelovati na radionicama i drugim događanjima vezanima uz gluhe?

DASč (Akulturacija u kulturu čujućih) - podskala Sudjelovanje u kulturi čujućih (Sudjelovanječ):

Koliko uživate družiti se s čujućima?

Koliko uživate ići na događaje/zabave/okupljanja čujućih?

Koliko uživate ići na kazališne predstave u kojima glume čujuće glumice/glumci?

Koliko uživate sudjelovati u političkim aktivnostima čujućih?

Koliko uživate sudjelovati na radionicama u čujućem svijetu?

Koliko uživate nastupati u sportskim natjecanjima čujućih i gledati ih? 
DASg (Akulturacija u kulturu Gluhih) - podskala Kulturne sklonosti (prema kulturi Gluhih) - Sklonostig:

Više bih volio/voljela ići u školu za gluhe.

Kada bih trebao/la s nekim dijeliti sobu, želio/željela bih da to bude gluha osoba.

Volio/voljela bih da u moju crkvu dolaze pretežno gluhe osobe.

Radije bih da je moj partner/bračni partner gluha osoba.

Volio/voljela bih da su moji najbolji prijatelji gluhe osobe.

Radije bih imao/la gluhu djecu.

Radije bih da moja radna okolina bude gluha.

DASč (Akulturacija u kulturu čujućih) - podskala Kulturne sklonosti (prema kulturi čujućih) - Sklonostič:

Više bih volio/voljela da moja djeca budu čujuća.

Više bih volio/voljela da moja radna okolina bude čujuća.

Radije bih išao u redovnu školu.

Kada bih trebao/la s nekim dijeliti sobu, želio/željela bih da to bude čujuća osoba.

Volio/voljela bih da su moji najbolji prijatelji čujuće osobe.

Više bih volio/voljela da je moj partner/bračni partner čujuća osoba.

Više bih volio/voljela da u moju crkvu dolaze pretežno čujuće osobe.

DASg (Akulturacija u kulturu Gluhih) - podskala Kulturno znanje (o kulturi Gluhih) - Znanjeg:

Koliko dobro poznajete tradicije i običaje u školama za gluhe?

Koliko dobro poznajete imena junaka ili poznatih gluhih osoba?

Koliko dobro poznajete važne događaje u povijesti zajednice gluhih?

Koliko dobro poznajete političke vođe iz zajednice gluhih?

Koliko dobro poznajete organizacije gluhih osoba i organizacije za gluhe osobe?

DASč (Akulturacija u kulturu čujućih) - podskala Kulturno znanje (o kulturi čujućih) - Znanječ:

Koliko dobro poznajete važne događaje u hrvatskoj/svjetskoj povijesti?

Koliko dobro poznajete imena čujućih hrvatskih junaka?

Koliko dobro poznajete imena popularnih časopisa i novina čujućih zajednica?

Koliko dobro poznajete imena slavnih čujućih glumica i glumaca?

Koliko dobro poznajete imena poznatih čujućih političkih vođa? 
DASg (Akulturacija u kulturu Gluhih) - podskala Jezična kompetencija - jezik gluhih (Jezikg):

Koliko dobro koristite hrvatski znakovni jezik (HZJ)?

Koliko dobro razumijete druge osobe koje koriste HZJ?

Kada koristite HZJ, koliko dobro Vas druge gluhe osobe razumiju?

Koliko dobro koristite ručne abecede?

Koliko dobro razumijete kada druge osobe koriste ručne abecede?

Koliko dobro poznajete žargon u HZJ-u ili popularne izraze u HZJ-u?

DASč (Akulturacija u kulturu čujućih) - podskala Jezična kompetencija - jezik čujućih (Jezikč):

Koliko dobro govorite hrvatski jezik?

Općenito, koliko dobro čujuće osobe razumiju Vaš govor?

Koliko dobro razumijete govor drugih osoba? (Koliko dobro čitate s usana?)

Koliko dobro razumijete tekstove koje čitate?

Koliko dobro pišete?

Koliko dobro poznajete fraze ili izraze na hrvatskom jeziku? 